\title{
Discursa, Lola, discursa: estratégias discursivas de um blog feminista
}

\author{
Carla Candida Rizzotto
}

Resumo: Este artigo procurou dar luz às estratégias discursivas do blog feminista Escreva Lola escreva a partir da teoria dos contratos comunicacionais Charaudeau. Tal contrato é pautado nos dados externos - condição de identidade, finalidade, propósito e dispositivo - e internos espaço de locução, relação e tematização - do discurso. Para identificar as características do contrato foi analisada uma amostra de 102 textos que versavam sobre a influência do discurso midiático na manutenção das características patriarcais da sociedade brasileira. Verificouse que o blog criticou mais frequentemente $(38,61 \%)$ o tratamento dos casos de violência contra a mulher, procurando trazer à tona a responsabilidade da mídia na chamada "cultura do estupro". Concluiu-se que o contrato firmado entre o blog e seu público é pautado em uma relação bidirecional, visando difundir uma cultura de consumo crítico das informações.

Palavras-chave: crítica de mídia; gênero; contratos comunicacionais.

Abstract: Speak, Lola, speak: discursive strategies of a feminist blog - This article seeks to shed light on the discursive strategies of the feminist blog Escreva Lola Escreva, based on Patrick Charaudeau's theory of Communication Contracts. Such contracts are based on external (condition of identity, purpose, content and material circumstances) and internal information (locutory space, relationship and theming) about the discourse. To identify the characteristics of the contract, an analysis is made of a sample of 102 texts about the influence of media discourse on the maintenance of the patriarchal characteristics of Brazilian society. It was found that the blog most often (38.61\%) criticizes the handling of cases of violence against women, seeking to bring to light the media's responsibility for the so-called "rape culture." It was concluded that the agreement between the blog in question and its audience is based on a two way relationship imed at disseminating a culture of critical consumption of information.

Keywords: criticism of media; gender; communication contracts.

Nos anos mais recentes, é possível visualizar com maior clareza que, apesar do alto grau de poder a qual detém, a mídia encontra ações de resistência na sociedade, que surgem em decorrência da alta centralização midiática, da falta de diversidade 
e consequente parcialidade dos conteúdos e da reprodução de pautas culturais que influenciam a interiorização de modelos sociais e estereótipos. ${ }^{1}$

Tal resistência, seja ela popular ou especializada, é identificada em diferentes ações de resposta e de interação da sociedade com a mídia, constituindo uma das forças responsáveis por uma ainda insipiente mudança de postura da grande mídia. Ramonet (2013) denomina tais experiências de "quinto poder". Este artigo é um recorte de pesquisa doutoral que investigou as estratégias de comunicação utilizadas por algumas dessas experiências para realizar o confronto com a mídia de massa e influenciar o público.

Aqui se analisam as estratégias do blog feminista Escreva Lola escreva² (ELE), escolhido pelo seu interesse específico no discurso midiático: sua influência para a manutenção das características patriarcais ${ }^{3}$ da sociedade. Sua atuação está centrada no combate à visão hegemônica dos papéis de gênero reproduzida pela mídia. Dessa forma, espera-se contribuir para a ampliação do campo de discussão sobre mídia e gênero no Brasil, muito diverso no que diz respeito à identificação da midiatização das relações de gênero (COSTA et al, 2012 e FUNCK; WIDHOLZER, 2005), porém ainda insipiente no estudo de experiências de resistência.

Como perspectiva teórico-metodológica foram revisados os conceitos de "contratos comunicacionais" (CHARAUDEAU, 2007), "contrato de leitura" (VERÓN, 1989) e "promessa dos gêneros" (JOST, 1987), e optou-se pela utilização do primeiro devido à importância heurística outorgada ao postulado da negociação de sentido entre o produtor da mensagem e o receptor, na mesma direção do realizado por Primo (2008) em pesquisa acerca da inserção dos blogs na estrutura midiática contemporânea. O autor justifica a utilização do conceito de "contrato comunicacional" como forma de investigar as condições de interação e reconhecer as restrições de uma dada situação de comunicação.

Esse referencial é utilizado aqui visando diversificar o universo das pesquisas sobre crítica de mídia no Brasil. Após a proliferação dessas iniciativas foi possível notar um crescimento das pesquisas a respeito (CHRISTOFOLETTI, 2008 e EGYPTO; MALIN, 2008), porém, a maioria delas se limita à conceituação e levantamento de experiências, deixando de lado a identificação de estratégias e relações com a mídia comercial.

Assim, é objetivo deste artigo identificar e analisar as estratégias através das quais o blog estudado conquista um espaço de fala perante seu público, para, a partir disso, identificar as características do contrato comunicacional estabelecido entre os dois e compreender o papel da crítica de mídia na relação entre a mídia e o público.

1 Estereótipos são entendidos aqui como um conjunto de crenças e opiniões, formados mediante um processo de generalização, que consideram que todos os membros de um grupo se comportam de um mesmo modo ou possuem as mesmas características. Os estereótipos de gênero, assunto específico deste artigo, são aqueles que tendem a separar características femininas e masculinas, por exemplo. mulheres são mais sensíveis e homens são mais fortes.

2 Disponível em: <http://www.escrevalolaescreva.blogspot.com>.

3 Entende-se o patriarcado como um sistema histórico e social utilizado para reforçar a diferença de poder entre homens e mulheres, cujas melhorias sociais privilegiam os homens. 
O conceito de "contrato comunicacional" é adequado por pressupor uma relação baseada em expectativas, regras e padrões, contrariando a ideia de manipulação pura e simples nas relações de poder.

\section{Gênero e mídia}

O blog Escreva Lola escreva foi escolhido como objeto de investigação devido ao recorte que realiza dos acontecimentos, ou seja, sua condição de propósito. A crítica de mídia realizada por ele possui o objetivo de combater o modelo preestabelecido das relações de gênero reproduzido pelos meios de comunicação, que "insiste[n] en presentar a la audiencia reconstrucciones ideológicas en las que la concentración de poder y el control del orden mundial está em mano de los varones [...]" (PLAZA; DELGADO, 2007, p. 8).

Para entender o modo como a mídia trata as questões relativas à mulher, e assim entender o propósito do blog aqui analisado, é preciso primeiramente abordar o conceito de gênero. De maneira bastante sintética, pode-se dizer que quando se fala em gênero se faz referência às características, condutas e papéis considerados como masculinos ou femininos em determinada cultura e em determinado período histórico. Gênero é, portanto, uma construção social, e não uma determinação biológica como muito se tenta, ainda hoje, também através da mídia, fazer crer.

Gênero foi inicialmente utilizado pela linguística, fazendo referência às categorias gramaticais dos substantivos, artigos, adjetivos e pronomes. A dimensão política só começou a ser abordada entre os anos 1960 e 1970 ao se discutir as relações sociais desiguais entre homens e mulheres (PULEO, 2007).

Ayala (2007), em estudo a respeito da linguagem jornalística e a discriminação de gênero, procura mostrar, através da representação desigual entre homens e mulheres, realizada pelo jornalismo tanto de maneira icônica quanto textual, que os meios de comunicação de massa propagam e aprofundam as diferenças entre os gêneros. Quantitativamente, a autora cita diversos estudos, dentre eles o "Who makes the news?" realizado pelo Global Media Monitoring Project, em 2005, que mostra em números essa desigualdade: os homens são protagonistas das notícias em $79 \%$ delas, enquanto as mulheres o são somente em $21 \%$. Nas poucas vezes em que elas são as protagonistas, são retratadas como um "objeto observado" e não como um "sujeito que atua", são julgadas pelo que são e não pelo que fazem, são vistas como "visitantes", como o "outro".

A autora cita manchetes de jornais espanhóis que comprovam essa afirmação: "La bella recupera el trono", "La sirena del mundo", "Mujer al mando", "Una mujer para gobernar Alemania", "La Barbie de Hierro". Todas evidências de que as mulheres são frequentemente julgadas e retratadas pela mídia com base em estereótipos e status de gênero. Se suas atitudes correspondem ao que culturalmente se espera do universo tradicional feminino são qualificadas como banais, caso contrário são qualificadas como frias e ambiciosas (AYALA, 2007). 
Pesquisas evidenciaram características da cobertura realizada pela mídia comercial das campanhas de mulheres candidatas a cargos públicos: frequentemente as candidatas mulheres recebem menos atenção da mídia do que os seus oponentes do sexo masculino (JALALZAI, 2006); as discussões a respeito das políticas focam assuntos triviais como sua aparência física e estilo de vida (MCCHESNEY, 1999); as mulheres recebem cobertura mais negativa a respeito da falta de experiência e conhecimento (CARLIN; WINFREY, 2009) e são frequentemente questionadas sobre assuntos culturalmente definidos como femininos, tais como aborto, educação e meio ambiente (HELDMAN, 2009).

Quando o assunto é a violência de gênero ${ }^{4}$ é usual a mídia considerar e retratar culpados de crimes contra mulheres como uma exceção - o monstro, o animal, o louco -, concluindo que "homens normais" não cometem esse tipo de crime. Geralmente mascarando crimes de ódio, ao se referir a feminicídios como "tragédias" provocadas por "monstros". De acordo com Byerly e Ross (2006, p. 42-3),

o enquadramento dos crimes sexuais como "ocorrências inusuais" levadas a cabo por "homens anormais" encoraja o ponto de vista que classifica tais crimes como raros e resultado de uma patologia individual que requer uma resposta legal, ao invés de constituí-los como um sério problema social que requer como solução uma reforma social. (tradução do autor)

Na publicidade, a representação da mulher sofreu pouca variação ao longo da história desse campo, segue sendo retratada em um espaço privado, como dona de casa, rainha do lar e protetora dos valores familiares (MAGER; HELGESON, 2011 e PACK et. al, 2011). Ou então como mulher objeto, um corpo anônimo, fragmentado,

simplesmente uma mercadoria a mais. Com sua beleza e atrativos incita e convida diretamente à compra de determinado produto. É mostrada em anúncios de todos os tipos como uma "coisa bonita" e quase sempre sexualmente desejável, cuja obtenção é supostamente tão simples como a compra do que é ofertado pela imagem. (YRACHE JIMÉNEZ, 2007, p. 114) (Tradução do autor)

A IV Conferência Mundial sobre a Mulher, realizada em Beijing em 1995, teve como propósito estabelecer uma agenda de mudanças sociais necessárias para melhorar a situação da mulher em todo o mundo. Na conferência dois grandes objetivos foram estabelecidos: fomentar a participação e o acesso das mulheres aos meios de comunicação, através da igualdade de contratação e nomeação em cargos de responsabilidade, da elaboração de conteúdos feitos por e para as mulheres, da participação das mulheres na elaboração de códigos de ética profissionais e nos mecanismos de autorregulação; e,

4 Segundo o Instituto Cabo-Verdiano para a Igualdade e Equidade de Gênero, a violência de gênero se refere a qualquer ato de violência em função do gênero que dê ou possa dar origem a danos físicos, sexuais ou psicológicos, ou que provoquem ou possa provocar sofrimento das mulheres, incluindo as ameaças desses atos, a coação ou privação arbitrária de liberdade. (Disponível em: <http://www.icieg.cv/>. Acesso em 23 fev. 2013.). 
alterar a imagem da mulher difundida pelos meios, adotando medidas contra estereótipos sexistas e violência de gênero e apresentando uma imagem mais equilibrada da mulher (AZNAR, 2005).

O blog ELE busca, além dos propósitos citados acima, alfabetizar midiaticamente ${ }^{5}$ seu público, ou seja, ajudá-lo a entender como a mídia de massa funciona e como seus significados são produzidos, para, assim, compreender como utilizá-la com sabedoria. A análise discursiva dos textos componentes da amostra possibilitou a descrição explicativa das características de seu contrato comunicacional, permitindo identificar para além de seus objetivos, seu modo de atuação.

\section{Material e métodos}

Charaudeau (2007) divide as sociedades democráticas em três esferas que se interferem mutuamente, mas que, segundo ele, não respondem a uma hierarquia: a política, a civil e a midiática. O autor faz uma descrição exaustiva das características da esfera midiática e de seu discurso e, ainda, do modo como se relaciona com as outras duas esferas. Um dos objetivos deste trabalho é, com base nos estudos de Charaudeau, expor as características da crítica de mídia, de seu discurso e do modo como se relaciona com as esferas civil e midiática. Para tanto, em primeiro lugar, é fundamental entender o modo de funcionamento da esfera midiática e a metodologia de análise utilizada pelo autor.

A esfera midiática é formada por três lugares de construção de sentido: a instância de produção (o organismo de informação), o produto (texto midiático) e a instância de recepção (públicos), conforme a figura 1:

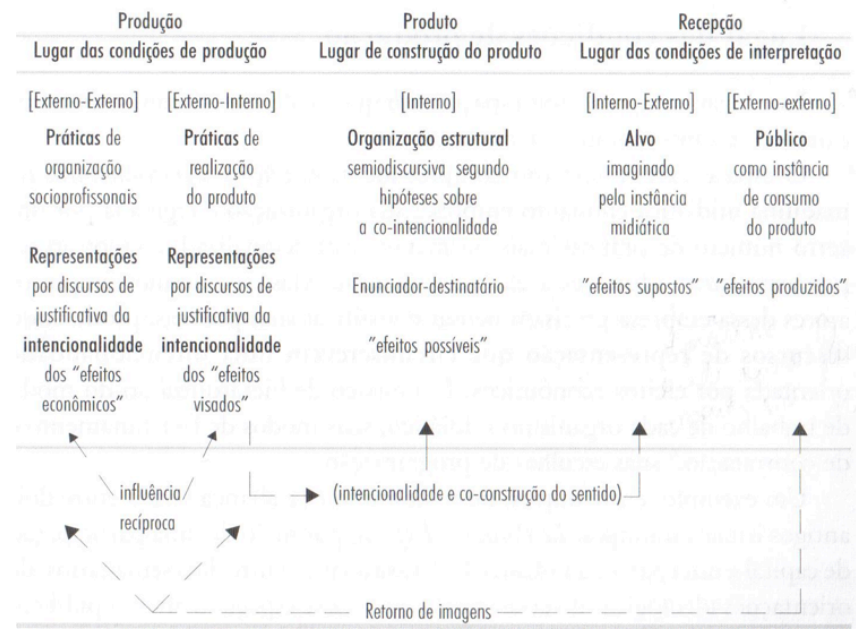

Fig. 1. Lugares de construção de sentidos. Fonte: Charaudeau (2007, p. 23).

5 A alfabetização midiática é, assim como alfabetização tradicional, a habilidade para ler, escrever e compreender informações. Porém, trata de informações audiovisuais, ou seja, em um primeiro nível é a habilidade para usar as mídias e compreender a informação recebida; em um segundo nível, abrange ainda a análise crítica, ou seja, questionar, analisar e avaliar a informação audiovisual. 
A instância de produção é formada por dois espaços distintos: o "externo-externo" representa as condições socioeconômicas da mídia vista como empresa, formada por práticas institucionais que determinam a busca quantitativa pela audiência; o "externointerno" representa as condições semiológicas da produção, diretamente relacionadas com o produto midiático, ou seja, determina a busca qualitativa pela audiência, ou "alvo ideal".

Para o autor, a audiência é impossível de ser dominada totalmente, o que faz com que as práticas semiológicas da instância de produção somente sejam orientadas por "efeitos de sentido visados", uma vez que os efeitos produzidos no receptor não correspondem integralmente aos efeitos pretendidos pela instância midiática. É justamente com base nessa relação de efeitos visados versus efeitos alcançados que se justifica a divisão dos dois espaços da instância de recepção: o "interno-externo", em que se encontra o alvo ideal como imaginado pela instância de produção (efeitos visados); e o "externo-externo", em que se encontra o alvo real, que atua de acordo com suas próprias condições de significação.

A terceira instância, representada pelo produto propriamente dito, é o local de estruturação de formas verbais ou semiológicas para formação do efeito de sentido. O sentido do texto, porém, é formado pela "cointencionalidade" entre emissor e receptor, portanto, o texto somente é portador de "efeitos de sentido possíveis", surgidos da imbricação entre os efeitos sentidos pela esfera da recepção e os efeitos visados pela esfera da produção (CHARAUDEAU, 2007 e 2011).

O relacionamento entre as três esferas é pautado pelo "contrato de comunicação", que se refere às condições vinculadas ao ato comunicacional que permitem que os interlocutores atribuam sentido a ele. Seu objetivo é permitir que os participantes entendam suas posições sociais e identifiquem a finalidade, a temática e as circunstâncias que definem o processo de comunicação em curso. Ele é resultado das características da relação entre os interlocutores, os dados externos, e das características do próprio discurso, os dados internos.

Para o estudo do discurso do ELE, a amostra consistiu em 102 textos publicados entre janeiro de 2008, data de surgimento do blog, e maio de 2013. O blog, que possui postagens diárias, publicou nesse período mais de 2 mil posts, entre textos sobre política, feminismo, mídia, crítica de cinema e guest posts. A amostra se restringiu aos textos que exerciam as funções da crítica de mídia, conforme explicadas por Christofoletti (2008): fiscalização dos meios de comunicação e alfabetização midiática da população. A coleta foi feita inicialmente utilizando os títulos como filtro, posteriormente cada um dos textos foi lido para uma segunda filtragem, garantindo que todos os textos analisados se referissem necessariamente à mídia e às questões de gênero. Para gerenciamento da amostra, foi criada uma base de dados. ${ }^{6}$

Após a delimitação da amostra, foram realizadas repetidas leituras para identificar as condições determinantes do contrato comunicacional. De cada um dos textos extraiu-se,

6 Disponível em: <http://www.inf.ufpr.br/carla/ base_de_dados $>$. 
num primeiro momento, sua finalidade - baseando-se na interpretação da tipologia discursiva e do tom comunicativo os textos, foram classificados como "fazer fazer", "fazer saber", "fazer crer" ou "fazer sentir" - e sua temática - procurando categorizá-la em cinco dimensões levantadas a partir da pesquisa de Aznar (2005) sobre o tratamento midiático das questões de gênero, quais sejam, violência contra a mulher, uso de estereótipos, invisibilidade da mulher na mídia, criação de um padrão de beleza inatingível e a cobertura da mídia sobre o feminismo como movimento social.

Em um segundo momento as leituras foram direcionadas para a identificação de marcas discursivas que indicavam o estabelecimento de uma relação entre a autora e o seu público. A partir disso foi possível abordar os efeitos da interpretação. Cabe ressaltar que é justamente nesta interpretação que recaem as limitações da análise discursiva, sendo fundamental, assim, o exercício constante de superação da simples descrição e compreensão subjetiva dos discursos.

Com o objetivo de obter informações complementares, elaborou-se questionário com perguntas abertas para a autora do blog, a professora Lola Aronovich.

\section{Análise e discussão dos resultados}

Conforme descrito acima, para determinar o contrato comunicacional é imprescindível analisar as condições externas ao discurso - os dados externos - e as características do próprio discurso - os dados internos. Os dados externos se dividem em quatro condições: identidade, reforçando o entendimento de que o discurso como ato de linguagem depende fundamentalmente dos sujeitos que participam dele ("quem se dirige a quem?"); finalidade, definindo que qualquer ato de comunicação deve ser orientado a um objetivo ("estamos aqui para dizer o quê?"); propósito, que requer que o processo de comunicação seja construído a partir de uma "maneira de recortar o mundo" ("do que se trata?"), já abordado em item anterior; e, dispositivo, relacionando o discurso com suas condições materiais ("em que ambiente se inscreve o ato de comunicação?") (CHARAUDEAU, 2007).

Para descrição da sua condição de identidade cabe esclarecer que o ELE nasceu como um blog de crônicas de cinema e ao longo do tempo foi se tornando um espaço das mais variadas discussões políticas. É um blog feminista, mas também se solidariza com as lutas de outros movimentos sociais, como o movimento LGBT, e busca discutir em seus posts diversos tipos de preconceitos, entre eles o racismo e a transfobia.

Da condição de identidade também faz parte a instância de recepção, todavia, é importante ressaltar que o foco deste trabalho é a crítica de mídia e o modo como ela estabelece suas estratégias de influência. Por isso a parte empírica foi desenhada com base nas estruturas discursivas elaboradas pelo emissor da mensagem. Ainda que o modo de elaboração da mensagem, pautado na relação estabelecida pelo blog com seu público, possa dizer bastante a respeito das suas características, neste estudo não foram abordados 
os aspectos relativos à recepção. Ainda assim, de maneira breve, algumas características acerca do público podem ser traçadas: segundo pesquisa realizada pela própria autora do blog, mais de $70 \%$ dos leitores possuem menos de 30 anos e $70 \%$ são mulheres. Segundo Lola Aronovich, ${ }^{7}$ seu público é jovem, está na escola ou na universidade, é de classe média e compartilha das suas opiniões.

De sua condição de dispositivo se destaca que os blogs caracterizam uma das diversas iniciativas que utilizam a internet como ferramenta de comunicação e se constituem meios de comunicação com grande potencial interativo que contribuem para um modelo de comunicação multidirecional. Usualmente se localizam entre o formal e o informal, o objetivo e o subjetivo e, por essa razão, instituem novas práticas discursivas e um novo modo dos receptores se relacionarem com os meios de comunicação e com a informação propriamente dita. Mas, além da materialidade do meio, é preciso observar ainda a posição relativa entre os participantes, o lugar e as circunstâncias da troca. Tendo isso em vista, Primo (2008, p. 3), define a especificidade dos blogs enquanto dispositivos:

A interface de comentários associada a cada post permite o debate pontual de textos. O link que indica o número de comentários do post funciona também como um convite para o debate. Essa interface é fundamental para o desenvolvimento de interações mútuas. Os debates no espaço de comentários ocorrem não apenas com o blogueiro, mas também entre os comentaristas. Nesse sentido, insiste-se aqui que um blog com comentários é um processo de escrita coletiva. Ou seja, um blog/texto é a somatória dos posts do blogueiro com as interações com e entre comentaristas no blog/espaço. [...] Com o tempo, e mediante a participação continuada na janela de comentários, um sentimento de grupo pode emergir a tal ponto de formar-se uma comunidade virtual que reúne-se naquele blog/espaço.

A condição de finalidade dos contratos comunicacionais é definida por Charaudeau (2007) em termos de "fazer fazer", "fazer saber", "fazer crer" ou "fazer sentir". Foram classificados como "fazer fazer" os textos que realizavam a instigação direta de uma ação; como "fazer saber" os que realizavam a transmissão neutra de uma informação; como "fazer crer" os que apresentavam uma maior objetividade; e, por último, como "fazer sentir", os que, além de apresentar uma maior subjetividade, tratavam de estabelecer uma conversação com o receptor.

No presente estudo, conforme se observa na tabela 1, a maioria dos textos (88,23\%) tinham como finalidade "fazer sentir" e a minoria (4,9\%), "fazer fazer". Esses dados mostram um resultado interessante porque, em primeiro lugar, diferenciam os objetivos da crítica de mídia dos objetivos da própria mídia, que possui a finalidade informativa como principal; e, em segundo lugar, porque permite categorizar o objeto como uma experiência de crítica de mídia que pretende, acima de tudo, alfabetizar midiaticamente a população através da argumentação (fazer crer) e da sensibilização (fazer sentir) e, em menor medida, influenciar o trabalho dos jornalistas e publicitários (fazer fazer).

7 Informações obtidas por meio de questionário respondido por Lola Aronovich em outubro de 2013. 


\begin{tabular}{|c|c|c|c|c|c|c|c|c|}
\hline & \multicolumn{2}{|c|}{ Fazer Saber } & \multicolumn{2}{c|}{ Fazer Fazer } & \multicolumn{2}{c|}{ Fazer Crer } & \multicolumn{2}{c|}{ Fazer Sentir } \\
\hline & $\mathrm{N}$ & $\%$ & $\mathrm{~N}$ & $\%$ & $\mathrm{~N}$ & $\%$ & $\mathrm{~N}$ & $\%$ \\
\hline Finalidade principal & 3 & 2.94 & 0 & 0 & 39 & 38.24 & 60 & 58.82 \\
\hline Finalidade secundária & 13 & 12.74 & 5 & 4.9 & 21 & 20.58 & 30 & 29.41 \\
\hline Total & 16 & 15.68 & 5 & 4.9 & 60 & 58.82 & 90 & 88.23 \\
\hline
\end{tabular}

Tab.1. Condição de finalidade ${ }^{8}$

Passando aos dados internos, estes se referem ao "como dizer", através de três espaços distintos: locução, relação e tematização.

O espaço de locução se refere às características do discurso e da atuação do emissor que fazem com que ele conquiste um espaço de fala perante seu público. Charaudeau (2011) explica que para isso o sujeito falante pode adotar diferentes estratégias discursivas: de neutralidade, em que não se percebe no discurso nenhum vestígio de avaliação pessoal; de distanciamento, quando o sujeito adota atitude controlada e especializada; ou, de engajamento, quando o sujeito toma posição e procura construir uma imagem de "ser de convicção".

No caso analisado ficou claro que a estratégia adotada é a de engajamento. Dar voz a outros sujeitos que reafirmam a importância da discussão a respeito dos diversos tipos de preconceito; tratar de assuntos variados e atuais que fazem parte da agenda de discussão do público-alvo; uso de títulos atrativos; uso de linguagem emocional que sensibiliza e auxilia a criação de laços afetivos com o público; uso de linguagem coloquial, ironia e humor como estratégias de aproximação; constante divulgação dos números de acesso do blog, que comprovam o alcance e, consequentemente, dão credibilidade a ele; e, demonstrações de conhecimento teórico acerca da temática feminista, são algumas das características do modo de produção discursiva que corroboram esta afirmação.

Para descrever o espaço de relação, a análise dos textos aqui realizada procurou determinar as marcas do ato linguageiro, para então concluir como o discurso promove a aliança ou a oposição com o destinatário. $\mathrm{O}$ "outro", de acordo com o que os posts analisados demonstram, é representado na figura do "machista", do "conservador", do "politicamente incorreto" e do "preconceituoso". Já com os leitores, a relação estabelecida é de proximidade e intimidade, e pode ser percebida a partir de algumas marcas discursivas apreendidas dos trechos selecionados, como a exposição de fatos e experiências pessoais; a utilização de questionamentos, estimulando a participação dos leitores por meio de comentários; e a utilização de elementos de linguagem que marcam um contato direto com o público.

8 A soma total das porcentagens é maior do que 100\% uma vez que alguns textos apresentam mais de uma finalidade ao mesmo tempo. 
No espaço de tematização, como dito, o emissor do discurso toma posição em relação ao tema imposto pelo contrato e escolhe um modo de intervenção. O ELE luta para que os veículos de comunicação contemplem certas dimensões na informação que produzem a respeito das mulheres.

Na figura 2, observa-se que a violência é a temática mais frequentemente tratada no blog ELE. A autora geralmente questiona a presença de preconceitos contra minorias no humor brasileiro e a naturalização da violência contra a mulher na programação televisiva, discutindo os limites que devem ser estabelecidos para combater a "cultura do estupro".

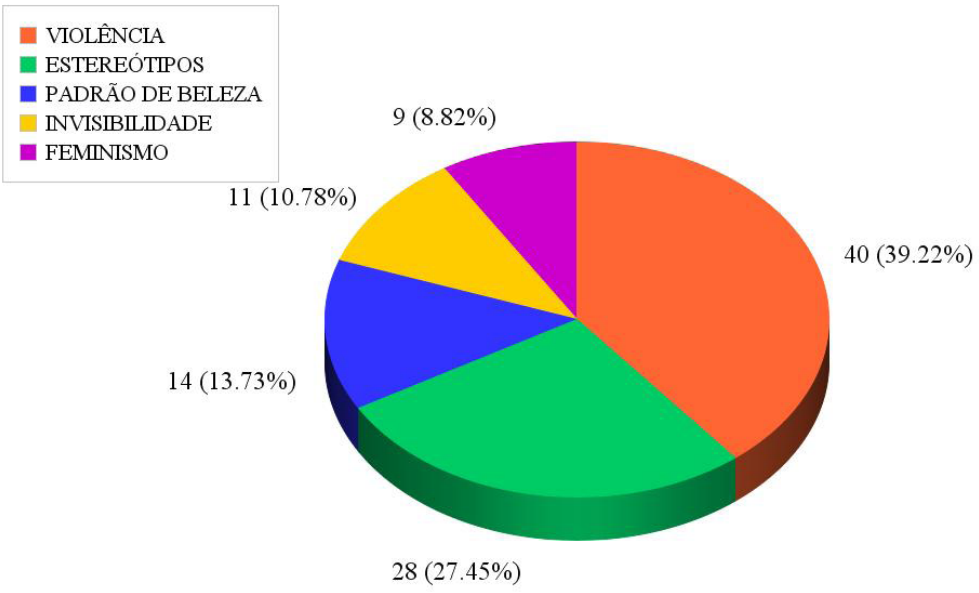

Fig.2. Espaço de Tematização ELE. Fonte: Elaboração própria.

Quanto aos estereótipos, o ELE enfoca na explicação biológica da diferenciação entre homens e mulheres pelos anúncios publicitários, programas de televisão e notícias jornalísticas. Sobre padrão de beleza, condena a indústria da beleza que cria padrões inatingíveis, em especial por meio de anúncios publicitários, para fazer com que as mulheres consumam. Os textos categorizados dentro da temática "invisibilidade da mulher" discorrem sobre a representação das mulheres na mídia, em especial políticas e esportistas, que quase sempre são retratadas somente em função da sua adequação ao padrão de beleza vigente. Na última categoria temática, encaixam-se textos que tratam do movimento feminista e do modo como sua definição e características são deturpadas pela mídia.

A análise das circunstâncias do contrato comunicacional da crítica midiática permitiu a elaboração de uma representação gráfica desse contrato, conforme figura 3. Dela extraiu-se os papéis assumidos pelos três participantes do contrato: (a) a instância de produção é responsável pelo processo de transformação do acontecimento bruto em acontecimento construído; (b) a instância de crítica de mídia parte do acontecimento construído e, através do que aqui chamamos de processo de crítica, gera o acontecimento 
criticado, ou seja, expõe e compartilha a sua visão de mundo a respeito do acontecimento construído pela instância midiática; e (c) a instância de recepção, que originalmente realizava um processo de interpretação partindo do acontecimento construído e gerando o acontecimento interpretado, com a inclusão da instância de crítica midiática passa a realizar um duplo processo de interpretação, uma vez que agora gera a sua interpretação do acontecimento com base no acontecimento construído pela mídia e também no acontecimento criticado pelas experiências de crítica de mídia.

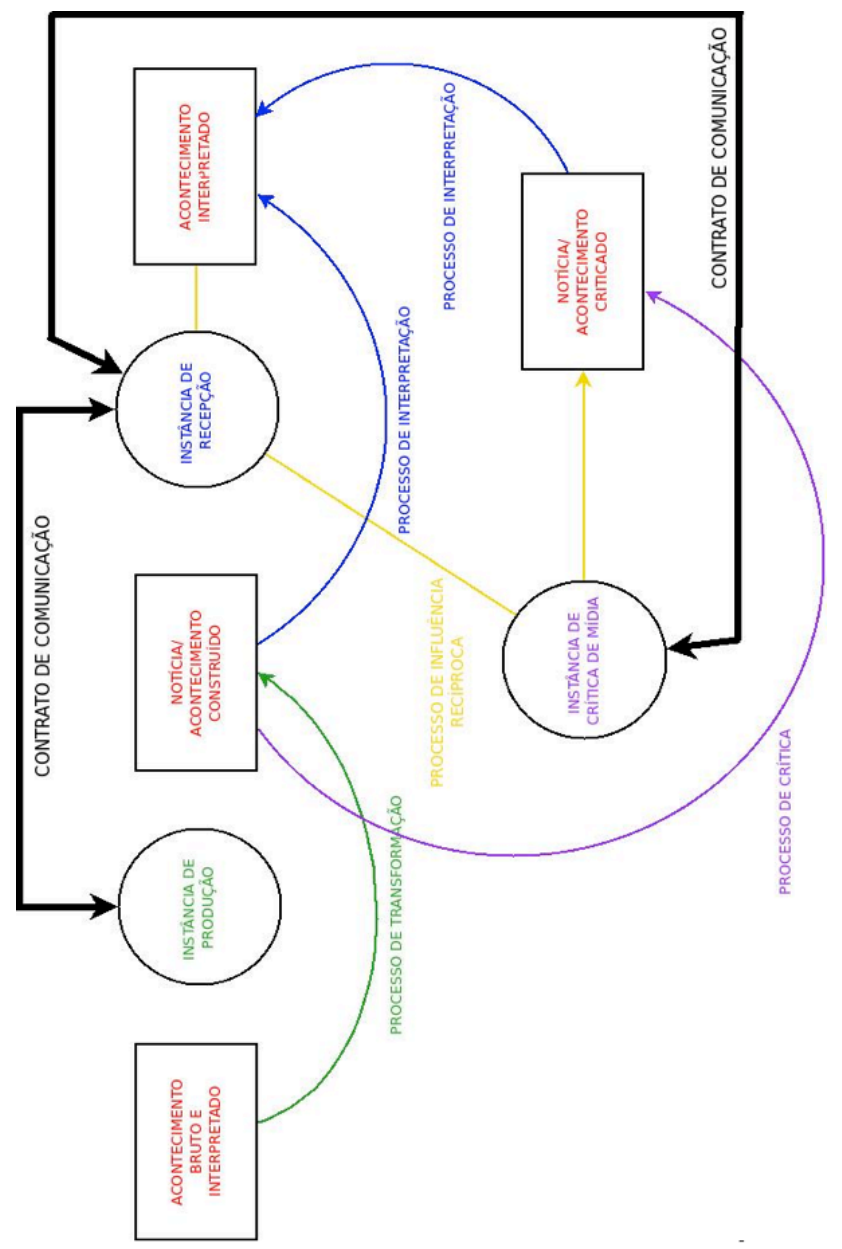

Fig. 3. Contrato Comunicacional da Crítica Midiática. Fonte: adaptado de Charaudeau (2007, p. 114).

Faz parte do contrato, ainda, o processo de influência recíproca, que se dá pela relação bidirecional estabelecida entre o blog e o seu público. Esse processo faz com que 
a crítica de mídia, facilitada pelo dispositivo pelo qual se realiza, leve em conta também a visão de mundo do público no momento de elaboração do acontecimento criticado.

\section{Considerações finais}

Este trabalho, embasado na teoria semiolinguística do discurso de Charaudeau, traçou as características do contrato comunicacional de uma experiência de crítica de mídia, o blog Escreva Lola escreva. A descrição e análise dos dados do discurso do referido objeto orientou as conclusões a respeito das funções da crítica de mídia no sentido de que ela deve ser realizada como uma atividade permanente de contraponto à mídia de massa. Quer dizer, o foco de uma experiência que se deseja efetiva não deve alterar o modo de atuação dos veículos tradicionais - ainda que esta tentativa não a deslegitime; mas, sim, o oferecimento contínuo de ferramentas que auxiliem o processo de interpretação realizado pela instância protagonista do contrato: o receptor.

Existe, porém, uma limitação nesta pesquisa que deve ser observada e direcionada a um estudo futuro: ainda que tenhamos tratado de um contrato comunicacional que tem o público como protagonista, esse público não fez parte do estudo. Olhamos o contrato sempre do ponto de vista da crítica midiática, procurando compreender o modo como se relaciona com as outras duas instâncias participantes. Portanto, as conclusões apontadas dizem respeito às intenções daquela instância materializadas através do discurso, mas não podem ser vistas como resultados definitivos a respeito de como o público se posiciona nesse contrato, tampouco do modo como ele efetivamente interpreta e utiliza a crítica para a formação da sua visão de mundo.

Ainda assim, reafirma-se a importância dos apontamentos acerca da influência recíproca entre a crítica de mídia e o público, pois, mesmo que tal evidência não tenha sido buscada no receptor, ela transparece em três componentes do contrato: na condição de finalidade que traça as intenções do emissor; na condição de dispositivo, visto que, como destacado por Primo (2008, p. 3), um blog com comentários é um "processo de escrita coletiva"; e ainda no espaço de relação, através do qual foram identificadas, no emissor, estratégias discursivas de aproximação com o receptor.

Daí as contribuições do artigo - sobretudo diante das atuais mudanças no relacionamento entre a mídia e o público, já que este último não é mais definido como espectador passivo: em primeiro lugar, para as pesquisas que tratam da crítica de mídia, pois procurou oferecer uma compreensão acerca das estratégias utilizadas pelo corpus e não se limitou à sua simples descrição. Ainda, para a área de mídia e gênero, por ir além da análise do modo de tratamento das questões de gênero por parte dos veículos de comunicação, tendo focado em uma experiência prática de contraposição e enfrentamento que serve como exemplo para outras iniciativas que visem difundir uma cultura de consumo crítico das informações. 
Carla Candida Rizzotto é doutora em Comunicação e Linguagens pela Universidade Tuiuti do Paraná e pósdoutoranda no PPGCom da Universidade Federal do Paraná, com bolsa Capes PNPD.

carla_rizzotto@yahoo.com.br

\section{Referências}

AYALA, J. G. Lenguaje periodístico y discriminación de género. In: PLAZA, J. F.; DELGADO, C. (orgs.). Género y comunicación. Madrid: Fundamentos, 2007.

AZNAR, H. Ética de la comunicación y nuevos retos sociales. Códigos y recomendaciones para los medios. Barcelona: Paidós, 2005.

BYERLY, C. M; ROSS, K. Women and Media: A critical Introduction. Oxford: Blackwell, 2006.

CARLIN, D. B.; WINFREY, K. L. Have you come a long way, baby? Hillary Clinton, Sarah Palin, and Sexism in 2008 Campaign Coverage. Communication Studies, 60 (4), p. 326-343, 2009.

CHARAUDEAU, P. Discurso das mídias. São Paulo: Contexto, 2007.

. Las emociones como efectos de discurso. Revista Versión, n. 26, UAM, p. 97-118, jun. 2011.

CHRISTOFOlETTI, R. Ver, olhar, observar. In: CHRISTOFOlETTI, R.; MOTTA, L. G. (orgs.). Observatórios de mídia. Olhares da cidadania. São Paulo: Paulus, 2008.

COSTA, M. M. M. et al. Discurso e poder: a midiatização das relações de gênero. In: CONGRESSO INTERNACIONAL DE DIREITO E CONTEMPORANEIDADE, Santa Maria. Anais... Santa Maria, Universidade Federal de Santa Maria, 30-31 maio e 1 jun. 2012.

EGYPTO, L.; MALIN, M. Um observatório, mais observatórios. In: CHRISTOFOLETTI, R.; MOTTA, L.G. (orgs.). Observatórios de mídia. Olhares da cidadania. São Paulo: Paulus, 2008.

FUNCK, S. B.; WIDHOLZER, N. (orgs.). Gênero em Discursos da Mídia. Florianópolis/ Santa Cruz do Sul: Ed. Mulheres/ EDUNISC, 2005.

HELDMAN, C. From Ferraro to Palin: Sexism in Media Coverage of Female Vice Presidential Candidates. In: PRESENTED ATTHE AMERICAN POLITICAL SCIENCE ASSOCIATION. Anais... Toronto, Canada, 2009.

JALALZAI, F. Women candidates and the media: 1992-2000 elections. Politics and policy, 34, p. 606-633, 2006.

JOST, F. La promesse des genres. Réseaux, Paris, n. 81, jan-fev., 1987.

MAGER, J.; HELGESON, J. Fifty years of advertising images: some changing perspectives on role portrayals along with enduring consistences. Sex Roles, 64, p. 238-252, 2011.

MCCHESNEY, R. W. Rich media, poor democracy: communication politics in dubious time. Urbana: University of Illinois Press, 1999.

PACK, H. et al. Examination of gender-role portrayals in television advertising across seven countries. Sex Roles, 64, p. 192-207, 2011.

PLAZA, J. F.; DELGADO, C. Prefácio. In: (orgs.). Género y comunicación. Madrid: Fundamentos, 2007. 
PRIMO, A. Interney Blogs como micromídia digital: elementos para o estudo do encadeamento midiático. In: ENCONTRO ANUAL DA ASSOCIAÇÃO NACIONAL DOS PROGRAMAS DE PÓSGRADUAÇÃO EM COMUNICAÇÃO, 17, São Paulo. Anais... São Paulo, p.1-17, 2008.

PULEO, A. H. Introducción al concepto de género. In: PLAZA, J. F.; DELGADO, C. (orgs.). Género y comunicación. Madrid: Fundamentos, 2007.

RAMONET, I. Meios de comunicação: um poder a serviço de interesses privados? In: MORAES, D.; RAMONET, I.; SERRANO, P. Mídia, poder e contrapoder. Da concentração monopólica à democratização da informação. São Paulo/ Rio de Janeiro: Boitempo/ Faperj, 2013.

ROCHA, E. A mulher, o corpo e o silêncio: a identidade feminina nos anúncios publicitários. Revista Alceu, v. 2, n. 3, jul/dez., 2001.

VERÓN, E. El análisis del contrato de lectura, un nuevo método para los estudios de posicionamiento de los soportes de los media. In: Les medias: experiences, recherches actuelles, aplications. Paris: IREP, 1989.

YRACHE JIMENÉZ, L. Imagen de la mujer y el hombre en publicidad. In: PLAZA, J. F.; DELGADO, C. (orgs.). Género y comunicación. Madrid: Fundamentos, 2007. 